\author{
Krystyna Kleszczowa*, Kamilla TermińsKA** \\ *Uniwersytet Śląski w Katowicach, Instytut Języka Polskiego \\ ** Uniwersytet Śląski w Katowicach, Instytut Języka Angielskiego
}

\title{
Przekraczanie granic składni semantycznej Stanisława Karolaka
}

I nie wódź nas na pokuszenie (Mt 6,13)

Słowa klucze: składnia; struktura predykatowo-argumentowa; model pojęcia nakłaniania; współczesny język polski; ewolucja języka

Keywords: syntax; predicative-argumentative structure; model of the concept of persuasion; contemporary Polish language; language evolution

\section{Wstęp}

Każda gramatyka języka naturalnego - wyabstrahowany z niego system praw i reguł słownego odnoszenia się do świata $i$ do własnej podmiotowości - ma u podstaw ontologiczne i epistemologiczne zasady panujące $\mathrm{w}$ danej, kulturowo określonej zbiorowości. Podstawy filozoficzne składniowej części tzw. żółtej gramatyki (Karolak 1984) nie zostały explicite wydobyte (nawet w części bibliograficznej), lecz są stosunkowo łatwe do rozpoznania. Jest to bowiem dzieło, które w sposób wzorcowy wręcz wpisuje się w jedną $\mathrm{z}$ dwu odmian analitycznego nurtu filozofii języka, w panującym od lat dwudziestych XX wieku paradygmacie lingwistycznym. Materializuje sobą za- 
łożenia dotyczące „szkoły języka idealnego”, powstałej w Kole Wiedeńskim i efektywnie rozwijanej m. in. przez R. Carnapa, ,pierwszego” L. Wittgensteina, V. O. Quine'a, A. J. Ayera, H. Reichenbacha i samego B. Russella. Nie można w tym miejscu przemilczeć także logiczno-lingwistycznych inspiracji dokonaniami polskich przedstawicieli szkoły lwowsko-warszawskiej: szczególnie K. Ajdukiewicza, T. Kotarbińskiego, T. Czeżowskiego, A. Tarskiego i, nieco młodszego, R. Suszki, z drugiej, zaskakującej, strony, widoczne są wpływy średniowiecznych ustaleń Piotra Hiszpana i Williama Ockhama oraz gramatyków z Port-Royal.

Składnia semantyczna jest de facto semantyką zdaniową, a nawet ponadzdaniową, opartą na Chomsky'ańskim rozróżnieniu ${ }^{1}$ płaszczyzny głębokiej i powierzchniowej. Płaszczyzna głęboka to miejsce jedno-, dwu- i n-argumentowych predykatów niższego (przyjmujących w miejsce argumentów jedynie tzw. indeksy, wliczając $w$ nie nomina propria i deskrypcje określone) i wyższego (wymagających jako argumenty całych struktur predykatowo-argumentowych) rzędu. Indeksy są tworami łączącymi rzeczywistość ekstralingwistyczną z językiem i wskazują na unikalne elementy czasoprzestrzeni. Zgodnie z szeroko przyjętymi poglądami Bertranda Russella są to wyrażenia wskazujące na dostępne obserwacji przedmioty makroskopowe, upraszczając - osoby i rzeczy². Każde wyprowadzone na powierzchnię z głębinowej

1 Profesor Karolak protestował przeciwko doszukiwaniu się podobieństwa jego składni semantycznej z generatywizmem. Inna rzecz, że rozbicie na strukturę powierzchniową i głęboką jest bliźniaczo podobne do Hjelmslevowskiego rozróżnienia na płaszczyznę in praesentia i in absentia, a nawet na tradycyjne rozgraniczenie treści i zakresu. Wydaje się zresztą, że poszukiwanie porządku pod migotliwą i niedookreśloną warstwą dostępną empirii jest w ogóle wyznacznikiem postawy naukowej.

${ }^{2}$ Opozycyjnym rozwiązaniem jest uznanie prymarności danych zmysłowych. Obiekty makroskopowe są wobec nich wtórne (konstrukty logiczne), a zdania, które je wskazują są już zdaniami derywowanymi. Zagadnienie to wiąże się z szeroko dyskutowaną wśród brytyjskich filozofów analitycznych problematyką tzw. zdań obserwacyjnych, które miały stanowić język bazowy, narzędzie uprawiania nauki i w konsekwencji - całościowego, wyczerpującego, prawdziwego opisu świata. Dzięki odpowiednim regułom logicznym zdania te można przekształcać w zdania derywowane z jednej strony, z drugiej zaś wszelkie zdania prawdziwe (przyjąwszy teorię weryfikacjonizmu lub którąś z jego licznych odmian wersję) mogły zostać do tej bazy sprowadzone (zasada redukcjonizmu wyznawana m. in. przez Ayera). Stanowisko Russella jest nieco bardziej skomplikowane. Twierdząc, że istnieje „tylko jedna przestrzeń, której elementami są same perspektywy” (Russell 2000: 99), wyraża pogląd, że „Mając dany pewien przedmiot z jakiejś perspektywy, utwórzmy układ wszystkich przedmiotów ze wszystkich perspek- 
struktury predykatowo-argumentowej wyrażenie (tzn. wyraz, fraza, zdanie, wypowiedzenie), jeśli nie zawiera w sobie indeksów, jest wyrażeniem derywowanym; zredukowanym przez nieujawnianie argumentów (tzw. zerowanie) lub rozszerzonym przez kwantyfikację lub zastąpienie indeksów dodatkowymi wyrażeniami predykatywno-argumentowymi.

Tak śmiała koncepcja gramatyki, zawierająca w sobie próby formalizacji, budziła nadzieję na uniwersalizm poprzez dążenie do precyzji i jednoznaczności, a także poprzez odwołania do logiki, która wydawała się bezstronnym i absolutnie niezawodnym narzędziem. Odrzucała na „drugi plan” idiomatyczność wyrażeń języków naturalnych, czyniąc najważniejszymi reguły składniowe połączone z selekcją semantyczną. Jej radykalizm polegał też na zwróceniu się ku abstrakcyjnemu porządkowi „głębi” i zerwaniu z pełną wyjątków, „skompromitowaną" strukturą zdania SVO, zastąpioną w pewnym stopniu mechanizmem perspektywy funkcjonalnej i diatez. Jej założenia nie pozwalają jednak na objęcie sobą całego języka naturalnego z jego nieogarnionym bogactwem, co stało się przyczyną uznania za ,nonsensowne" obszernych enklaw języka naturalnego, np. niereferencjalnego języka szeroko rozumianej metafizyki, w dużej mierze języka potocznego i języka religii ${ }^{3}$. Brak referencji zastąpiła stosowana ad hoc presupozycja egzystencjalna, dzięki której można było mówić „sensownie” o bytach fikcyjnych w rodzaju „obecnych, łysych królów Francji”. Inne trudności okazały się jednak nie do przezwyciężenia: polisemia i otwartość znaczenia, metafora i rozchwiane reguły łączenia, redundancja i Ingardenowskie „miejsca puste”, paradoksy, alegorie i, mówiąc ogólnie, ekspresywno-impresywna, retoryczna figuratywność języka. Chociaż jest to koncepcja z założenia ahistoryczna, wypracowane w jej łamach procedury okazują się przydatne w badaniach historycznojęzykowych, a hasło powszechnie stosowane w ramach analitycz-

tyw, które są z nim skorelowane; układ ten można utożsamiać z chwilową „,rzeczą” zdrowego rozsądku... Wszystkie wyglądy rzeczy są realne, natomiast sama rzecz jest tylko konstrukcją logiczną" (Russell 2000: 99). Inny zorientowany lingwistycznie filozof pisze: „Teraz mogę sformułować moją tezę, powiadając, że linie światowe indywiduów nie są ustalone przez niezmienne prawa logiki, przez Boga ani żadną inną moc równie transcendentną, lecz zostały niejako poprowadzone przez nas - oczywiście nie przez każdego z osobna, ale przez milczącą decyzję zborową, ucieleśnioną w gramatyce i semantyce naszego języka" (Hintikka 1992: 136).

3 „Metafizyka” zaczęła w tym kręgu funkcjonować wręcz jako inwektywa stosowana wobec obszarów języka nie podlegających procedurom weryfikacjonistycznym. 
nej szkoły języka idealnego „If you take of the syntax, the semantics will take care of itself"4 okazuje się nadal przydatne.

W składni Stanisława Karolaka kluczowym terminem jest model PSPA - podstawowa struktura predykatowo-argumentowa, stworzona na podstawie liczby i typów implikowanych argumentów otwieranych przez predykat ${ }^{5}$. Profesor Karolak pisze: ,język polski dysponuje szeregami wyrażeń predykatywnych, będących wykładnikami tych samych predykatów. Różnią się one między sobą wymogami w zakresie liczby wypełnianych pozycji argumentowych, nie wykazując różnic w treści predykatywnej. Tak np. predykat skap-, którego wykładnikami są wyrażenia predykatywne skapić, skapy i skapiec, implikuje na płaszczyźnie semantycznej trzy argumenty: $x$ skapy-a z-owi" (Karolak 1984: 50). W dalszym ciągu przytacza przykłady wykładników innych predykatów:

nud- : nudzić się, znudzić się, nudzić, znudzić, nudny, znudzony, nudno, nuda, nudziarz;

stusz- : stuchać, postuchać, postuszny, postuszeństwo.

Jak widać, Karolak uchyla rolę morfologii, skupiając uwagę na rdzeniu PSPA $^{6}$. Ograniczenie to próbujemy przezwyciężyć, przekraczając, w dalszej części artykułu, granice koncepcji Karolaka.

4 Jest swoistym paradoksem, że szkoła, która programowo występuje przeciwko stosowaniu metafory w języku uprawiania nauki, posługuje się hasłem zawierającym w sobie antropomorfizację. Quandoque bonus dormitat Homerus..

5 Pisze Karolak (1984: 47): „W przyjętym modelu opisu PSPA podstawą ustalania semantyczno-syntaktycznej identyczności różnych wyrażeń predykatywnych jest identyczność implikacji syntaktycznych, czyli liczba i typy pozycji argumentowych otwieranych przez predykaty, których są one wykładnikami."

6 Wprawdzie pisze Profesor Karolak „Jedyna pewna procedura adekwatnego ustalenia liczby pozycji w konkretne PSPA polega na dokonaniu pełnej (optymalnej) dekompozycji sensu reprezentowanego przez dane wyrażenie predykatywne na składniki elementarne (dalej nierozkładalne), czyli na semy w badaniu semantycznych implikacji poszczególnych semów i przemnożeniu liczby pozycji implikowanych przez wszystkie składniki sensu z równoczesną redukcją liczby powtórzeń tej samej pozycji do jednej. Procedura ta zakłada wprawdzie konieczność dokonywania głębokich i subtelnych analiz semantycznych, ale pozwala na sporządzenie niesprzecznego i adekwatnego opisu semantyczno-syntaktycznego" (Karolak 1984: 54), lecz jej stosowaniu towarzyszą z konieczności liczne trudności, uproszczenia i uogólnienia. 
1. Budujemy abstrakcyjną strukturę predykatowo-argumentową dla większej klasy, uchylając wymóg identyczności rdzenia. Nie można takiej operacji uznać za rezygnację z założeń składni semantycznej, jest to raczej ich rozszerzenie, pozwalające ogarnąć większą ilość badanego materiału. Jedność rdzeni w pewnym zakresie jest aktualna (np. prosić, prośba, proszenie, proszacy czy radzić, rada, doradca, radzenie, poradzić, porada; żebrać, wyżebrać, żebrak, żebractwo), tworzymy model semantyczny dla klasy wyrażeń predykatywnych wyższego piętra. U podstaw stoi semantyka. Nie zamierzamy jednak całkowicie odrywać się od struktury języka. Zasadność wiązania różnordzennych wykładników abstrakcyjnego predykatu (= pojęcia) argumentujemy wymogami składniowo-morfologicznymi, specyfikującymi utworzony model.

Nazwijmy analizowany model NAKŁANIANIEM, choć nie uważamy, że najlepszym egzemplarzem jest tutaj leksem nakłaniać. Równie dobrze można by go nazwać np. INCYTATYWNOŚCIĄ albo EWOKOWANIEM. Pamiętajmy też, że termin jest sprawą umowną, a w polskiej literaturze utrwaliło się „nakłanianie” jako nazwa branej tu pod uwagę klasy PSPA (por. Czekańska 2015; Kleszczowa, Termińska 1983, 1999).

Abstrakcyjny model nakłaniania został utworzony poprzez nałożenie semantycznych restrykcji morfologiczno-składniowych. Można go nazwać schematem myślowym podpartym składnią paradygmatyczną. Ma on postać:

$$
\mathrm{C}_{\text {caus }} \mathrm{Z}_{1} x y \mathrm{Z}_{2} y^{7}
$$

gdzie

$x, y=$ argumenty osobowe;

$\mathrm{Z}_{1}, \mathrm{Z}_{2}=$ argumenty propozycjonalne wyższego rzędu, symbolizują działania intencjonalne;

$\mathrm{C}_{\text {caus }}=$ kauzacja, dwuargumentowy predykat wyższego rzędu, implikujący argumenty propozycjonalne.

7 Zastosowano notację wzorowaną na zaproponowanej przez J. Łukasiewicza (tzw. polish notation) i stosowanej przez T. Czeżowskiego. Główny predykat - kauzacja, którą nota bene Łukasiewicz utożsamia z implikacją, wysunięty jest w niej na czoło. Ale możliwy jest też inny zapis: $Z_{1}(x, y)$ Caus $Z_{2}(y)$. 
Wzór ten można odczytać jako funkcję zdaniową:

$x$ działając intencjonalnie wobec $y$ powoduje, że $y$ wykonuje/ bierze udział w $Z$ i zilustrować konkretyzującym ją zdaniem, np. Jan, powtarzając Piotrowi plotki, sprawia, że Piotr wpada $w$ depresję.

Każdy z argumentowych elementów SPA może ulegać niewypełnieniem, uzmiennieniom oraz dalszej predykacji, włączając $\mathrm{w}$ to kwantyfikację, np. Władza stosuje odpowiednie środki kontroli i przymusu, żeby efektywnie żadać od obywateli skrupulatnego i terminowego płacenia podatków w odpowiednim urzędzie skarbowym.

Powyższy model pozbawiony jest temporalności (powoduje, spowodowat, będzie powodować), chociaż wpisany w formułę związek przyczynowo-skutkowy narzuca rozumienie czasowości - wszak skutek nie może być wcześniejszy od przyczyny.

W modelu mieści się powodować, co jest wyraźnym sygnałem, że predykaty nakłaniania należą do ogólniejszej klasy kauzatywów. Wiadomo jednak, że kauzowanie nie musi dotyczyć innej osoby, por. Jan zmusza się do pracy (koincydencja agensów pierwszego i drugiego zdarzenia, refleksywizacja), że intencjonalne działanie $x$-a niekoniecznie wywołuje działania $y$-a, nawet jeśli modalność konieczności mieści się w strukturze predykatowo-argumentowej (np. Nauczyciel nakazał uczniom bezwzględne zachowanie ciszy, do czego się wcale nie zastosowali.) i że zachowanie pierwszego agensa nie musi nosić charakteru działania intencjonalnego nakierowanego na osiągnięcie celu (np. Bezczynność Jana wywołała agresję Piotra) (Termińska 1983). Żeby odrzucić bogactwo różnych typów kauzacji, stosujemy filtr morfologiczno-składniowy. Tak więc opieramy nasze rozumowanie na konstrukcjach, w których w roli wyrażenia wskazującego na związek przyczynowo-skutkowy występuje verbum, natomiast inne wykładniki implikowane przez PSPA mają morfologicznie określoną modelową postać:

$x=$ argument osobowy $\mathrm{w}$ postaci nominativu (Jan prosi, radzi, namawia);

$y=$ argument osobowy w postaci biernika (prosi Piotra, namawia Marię) lub

(ekskluzywnie) celownika (nakazuje Piotrowi, poleca Marii); 
$\mathrm{Z}_{1}=$ argument propozycjonalny wyrażający działanie intencjonalne $x$-a, ukierunkowane na $y$-a, który w następstwie staje się agensem działania $Z_{2}$;

działanie $Z_{1}$ musi mieć charakter znakowy, a statystycznie najczęściej mamy do czynienia $\mathrm{z}$ mówieniem;

$\mathrm{Z}_{2}=$ argument propozycjonalny $\mathrm{w}$ postaci:

bezokolicznika (radzi wyjechać)/

do $\mathrm{Z}^{\text {nominalizacja }}$ (namawia do wyjazdu)/

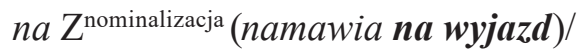

$k u \mathrm{Z}^{\text {nominalizacja }}$ (podżegać ku wojnie);

aby, żeby, by S (prosi, aby go odwiedzić),

czasami w miejscu $\mathrm{Z}_{2}$ pojawia się jeden z argumentów PSPA: prosi o kawę/ podżega przeciw nauczycielowi.

Wydzielona w rezultacie klasa NAKŁANIANIA ogarnia sobą wyrażenia werbalne typu kazać, prosić, żebrać, polecać, namawiać, poduszczać, zapalać kogoś do... itd. Mamy świadomość, że wyrażenia predykatywne, o których mówimy, nie muszą być realizowane w postaci czasowników, jednak, zgodnie z konwencją Profesora Karolaka, przy nich pozostaniemy, widząc przydatność w prowadzeniu naszych, z konieczności pełnych symplifikacji, analiz. Po pierwsze, wyrażenia czasownikowe w sposób ewidentny obrazują ilość i jakoś argumentów, przedmiotowych i nieprzedmiotowych. Drugi powód związany jest z morfologią. Uwikłanie rdzenia w wykładniki formalne - fleksyjne i słowotwórcze - zmienia czasami strukturę predykatowo-argumentową. Przytoczony wcześniej przymiotnik posłuszny w paśmie rdzenia stuch(ać) jest wykładnikiem innego predykatu, wskutek leksykalizacji wpisuje się w ciąg: stużebny, spolegliwy, ulegty.

Zdarza się, że cała PSPA nakłaniania jest zanurzona w innej; jest wtedy argumentem jakiejś nadrzędnej PSPA odmiennego typu, np. Jan jest zdegustowany, obserwujac, jak Piotr po raz kolejny prosi Marię o przystuge. Zjawiska te nie zostaną omówione w naszym artykule.

2. Zaprezentowany model zawiera w sobie wykładniki składniowe i morfologiczne, umożliwiające wewnętrzną partycję. I tak osobną klasę tworzą czasowniki mieszczące się $\mathrm{w}$ grupie: wynik $\mathrm{Z}_{2}$ jest korzystny dla $x$-a (pro- 
sić, błagać, dopominać się, dawne modlić kogoś o coś). W grupie tej mamy do czynienia $\mathrm{z}$ obligatoryjnym argumentem zdarzeniowym w postaci wyrażenia przyimkowego z o (prosić o życzliwa lekturę tekstu). Zdarza się, że przyimek $o$ wiąże argument przedmiotowy, por. Prosić o kawę. Z punktu widzenia współczesnej polszczyzny nie jest to proste nieujawnienie (tzw. wyzerowanie) argumentu zdarzeniowego, bo wówczas kawa byłaby w dopełniaczu: podanie kawy. Wgląd w historię polszczyzny zdradza takie możliwości, można było prosić o jatmużnę, także prosić jałmużny, prosić o chleb, też: prosić chleba ${ }^{8}$.

w którym [bractwie] chciał mieć dwanaście cnych i bogobojnych mężow/ ktorzyby jałmużny po mieście prosili/ na ty/ którzy się żebraćl [...] wstydza SkarŻyw 413 (SXVI);

gdy od jednego ubogiego chleba prosit, ci którzy tam przy tym byli temu się śmiali BielŻyw 73 (SXVI).

Ograniczenie rekcji tłumaczyć można krzyżowaniem się tej klasy predykatów nakłaniania $\mathrm{z}$ innym modelem predykatowo-argumentowym, mianowicie STARAĆ SIĘ O CO - starać się, zabiegać o co, dawne stać o coś, usiłować się o coś, kusić, pokuszać (a jeśliby mogła głowa na dół obrocić, a się o to pokuszać. FalZioł V 22d (SXVI)). Można powiedzieć, że w tej grupie korzyści dla $x$-a - ,prześwituje” inny model predykatowo-argumentowy, co znajduje odbicie we właściwościach składniowych podklasy predykatów nakłaniania.

Inną grupę tworzą wyrażenia predykatywne typu radzić, zalecać, podszeptywać, w których zdarzenie skutkowe jest korzystne dla $y$-a. Wyraźnie kształtuje się też klasa predykatów nakłaniania o ogólnym znaczeniu ' $x$ działa intencjonalnie, aby $y$ nie robił $\mathrm{Z}_{2}$, por. odradzać, odciagać, odwodzić, ostrzegać, wyperswadować, zabraniać, powstrzymywać.

Szczególnie interesująca jest klasa predykatów uwzględniająca wartościowanie. W pokazanym wyżej modelu NAKŁANIANIA mieszczą się czasowniki różne pod tym względem. Zdecydowana większość jest ambiwalentna odnośnie wartościowania - ten sam predykatyw raz odnosi się do sytuacji

${ }^{8}$ Do dziś mamy składnię wariantywną: dopominać się o śniadanie a. śniadania. 
$\mathrm{zZ}_{2}$ dodatnim, innym razem - ujemnym (namawia do ugoszczenia przyjezdnych / namawia do morderstwa). Ale są i takie czasowniki, które wiążą tylko $\mathrm{Z}_{2}$ wartościowane pozytywnie (zalecać, dawne: nęcić, powabiać) albo tylko negatywnie. I właśnie tym ostatnim zamierzamy przyjrzeć się bliżej.

Przypisywanie wartości zawsze stwarza niebezpieczeństwo subiektywizmu. Istnienie obszaru granicznego między stricte negatywnym i stricte pozytywnym biegunem ocen, w którym pojawia się wariantywna ambiwalentna, nie ulega wątpliwości. Wywikłanie się z niebezpieczeństwa subiektywizmu wymagałoby zastosowania tzw. definicji normatywnych (np. dorosty to 'ten, kto skończył 18 lat'), czego w tym artykule chciałybyśmy uniknąć.

2.1. Zapytać warto o strukturalno-semantyczne wykładniki negatywnego wartościowania. Najprostszą odpowiedzią jest explicite wyrażona negatywna wartość zdarzenia, do którego jest nakłaniany $y$, ale to, była o tym mowa wcześniej, nie jest wystarczającym wyróżnikiem klasy, bo zdecydowana większość predykatów nakłaniania jest w stanie wiązać $Z_{2}$ pozytywne, jak i negatywne. Tymczasem negatywne nacechowanie $Z_{2}$ jest warunkiem koniecznym dla naszej klasy. Zdanie Jan podpuszcza Marię, żeby okazała dziecku milość jest akceptowalne tylko warunkowo (w większym kontekście). Zatem negatywne nacechowanie $Z_{2}$ jest znamienne dla całej klasy, co więcej - jest jej podstawowym rysem.

2.2. Czy negatywne nacechowanie czynności Y-a związane jest z semantyką rdzenia wyrażenia predykatywnego? Okazuje się, że to bardzo rzadkie wypadki. Przykładem może być czasownik buntować, który utworzony jest na bazie nomen bunt, wartościowanego negatywnie? ${ }^{9}$ Dodać tu też można dawne znaczenie czasownika burzyć, co widać w cytacie: $i$ burza ich [diabłowie] jako wierne żołnierze swe ku roztargnieniu kościoła Bożego OrzList $\mathrm{d} 2 \mathrm{v}$ (SXVI).

2.3. Jeśli chodzi o syntaktyczne właściwości NAKŁANIANIA do złego, to jedynie w tej klasie może pojawić się wyrażenie przyimkowe przeciw/ przeciwko komuś jako uszczegółowienie $\mathrm{Z}_{2}$ (Jan podpuścit Piotra przeciwko teściowej). Z naszych obserwacji wynika również, że nakłaniany $y$ pojawia się na powierzchni jedynie w formie biernika.

${ }^{9}$ Chociaż kontekst może odwrócić znaki wartości, np. bunt przeciwko torturom stosowanym w Guantanamo / nieludzkiemu traktowaniu zwierząt itd. 
2.4. Uderzające jest częste pojawianie się prefiksu pod-: podburzać, podjudzać, podpuszczać, podszczuwać, poduszczać / poduścić, podmawiać/podmówić, podżegać, podsycać, dawne podwodzić. Można przyjąć, że u źródeł stoi przestrzenna funkcja $p o d-$ - działanie pod powierzchnią lokalizatora lub na jego dolnej części, np. podkopać, podpisać. Już w staropolszczyźnie odnotowane są inne funkcje kategorialne, np. czasowniki podbić, poddać, podgarnąć, podhołdować, które miały sens 'podporządkować sobie, podbić'. Już wtedy funkcjonowały czasowniki, którym można przypisać znaczenie 'zrobić coś ukradkiem', por.: podchwacić 'podejść, oszukać', podchycić 'podstępem zabrać', podkupić., także poduścić 'podstępnie doradzić, namówić, podpowiedzieć, podniecić'. Znaczenie 'uczynić coś potajemnie' mają dzisiejsze czasowniki z prefiksem pod-, por. podgladać, podstuchiwać, podmieniać, podrobić, podgryzać pot. 'działać skrycie i podstępnie na czyjąś szkodę'; 'intrygować'. Niejawne działania $x$-a to cecha całej klasy predykatów nakłaniania z negatywnym nacechowaniem. Trudno sobie wyobrazić użycie w pierwszej osobie czasu teraźniejszego, por. *Podpuszczam cię do zdrady, *Podżegam Cię do lekceważenia swoich obowiązów. Tym samym wyłania się następna cecha opisywanych przez nas predykatów, o czym będzie mowa za chwilę ${ }^{10}$.

Interesujące zjawisko leksykalizacji obserwujemy w czasowniku podpuszczać, który etymologicznie związany jest z rzeczownikiem usta, widać to wyraźniej w dawnym poduścić (Mienia tu niektórzy, iże mity Krystus nie karat świętego Piotra, ale szatana, który ji k temu poduścił Rozm 364 (SStp)). Początkowo poduszczaćl poduścić znaczyło 'namawiać/ namówić/ podpowiadać, niekoniecznie do złego, por. Stuchajże zasię jeszcze/[...] jako poduszczyć raczyt Tomasza świętego/ aby go pytat o tę drogę RejPos 293 (SXVI). W dalszym ciągu doszło do kontaminacji dwóch leksemów: poduszczać/ poduścić i podpuścić (mleko, chleb, por. podpuszczka). Czasownik

10 Szerzej na temat pod- we współczesnej polszczyźnie pisze K. Termińska (Termińska 2001). Wydziela 3 kompleksy znaczeń: 1. działanie od spodu ku górze (np. podkopat fundamenty domu, podpisat się in blanco, podsadził dziecko do okna i in.); 2. działanie niepochwytne, ukryte, podstępne, moralnie naganne, dyskretne, znienacka, progowe: Podgladat koleżanki; Podpowiadat na lekcji; Podrobit podpis w indeksie: Podszedt kolegę $i$ wyciagną z niego wiadomości; Podmówił klasę do pójścia na wagary; Podpuścit jednych znajomych na innych; 3. działanie częściowe, niedokładne, ze śladowymi, nikłymi rezultatami (m.in. Podczyściła kapelusz i schowała do szafy; Podleczyła się sokiem malinowym i przestała brać antybiotyk). 
wtórnie uległ resemantyzacji, czego efektem jest włączenie go do klasy innych leksemów o rdzeniu pust-/ puść- (puścić, odpuścić, przepuścić, wpuścić itd.). Zapewne nie bez znaczenia był omówiony w tym fragmencie artykułu przedrostek pod-.

2.5. Wyrażenia predykatywne modelu nakłaniania do złego nigdy nie są używane w funkcji czasowników performatywnych, tzn. w 1 os. czasu teraźniejszego. Jeżeli nawet to się zdarzy, jest to nadal opisywanie swojego działania, zwykle w sensie habitualnym, por. Podpuszczam ja, żeby zakładała te obcisłe spodnie, a ona myśli, że jest bardzo zgrabna.

2.6. Niektóre znaczenia negatywne można traktować jako efekt uwarunkowań kulturowych. Przykładem może być czasownik molestować, który w ostatnich dziesięcioleciach związał się ze sferą seksualną. Gdyśmy 30 lat temu pisały o molestowaniu, miałyśmy na uwadze tylko uporczywe, nachalne i długotrwałe proszenie, nagabywanie, np. Matka molestowała syna, aby włożyt cieple skarpety. Warto dodać, że tylko takie znaczenie odnotowane jest w SDor. Tymczasem dziś molestować to 'nakłaniać kogoś do kontaktów seksualnych, wykorzystując swoją przewagę, zwykle w stosunkach służbowych'. Można tu dopatrywać się ogólnego zjawiska językowego - jeżeli wyraz zwiąże się ze sferą seksualną bądź fizjologiczną, inne znaczenia wycofują się z języka (Kleszczowa 1993).

Gdy spojrzeć z punktu widzenia współczesnej polszczyzny, nacechowanie negatywne wnosi rdzeń czasownika judzić, użytkownik polszczyzny widzi w podstawie zdrajcę Judasza. Sprawa nie jest tak prosta. Jest to późna pożyczka wschodnia, notowana dopiero od XIX wieku (po raz pierwszy w SWil), a skojarzenie z Judaszem jest wtórne (SSław, SBor). Nie zmienia to jednak faktu, że powstał węzeł semantyczno-kulturowy.

Czasownik kusić spotykamy w całej słowiańszczyźnie, choć zapożyczony z goc. kausjan znaczył początkowo 'kosztować, próbować, doświadczać' (SBor). U progu polszczyzny kusić nie miało negatywnego nacechowania. Rzecz w tym, że w tekstach to zazwyczaj szatan wystawiał $y$-a na próbę, a on, wiadomo, kusi tylko do złego. Zatem o negatywnym nacechowaniu zadecydowały czynniki kulturowe.

3. Choć nie sygnalizowałyśmy tego wyraźnie, nasze dotychczasowe rozważania oparte były na szerszej bazie niż współczesna polszczyzna. Okazuje się, że zdecydowana większość zjawisk semantyczno-syntaktycznych 
NAKŁANIANIA wspólna jest współczesnym i historycznym wykładnikom predykacji. Oto kilka przykładów z przeszłości:

Często je [św. Piotr heretyków z Werony] do ognia [tj. do rozpalania ognia] POWABIAŁ mówiąc: o tę prawdę której ja uczę/ naniećcie ogień/ pojde ja ochotnie weń SkarZyw 373 (SXVI);

Tak to ja mówięl jako mówić cnemu Polakowi a wiernemu poddanemu Krola Polskiego przystoi: nie OSTRZAC Krola Pana swego na nikogo OrzQuin D3v (SXVI);

Czyli nas Pan Bog CIŚNIE i przymusza do niepodobnych rzeczy? WujNT 827 (SXVI);

POWIABIONO go, żeby to pisat. Wys. (SW).

3.1. Generalnie obserwuje się w klasie NAKŁANIANIA nie tyle zmiany składni, co ograniczanie wariantywności. Zmiany te dotyczą przede wszystkim formy argumentu $\mathrm{Z}_{2}$. Jak chodzi o argument odnoszący się do $y$, napotkałyśmy tylko dwa przykłady wariantywności formy $y-w$ bierniku lub celowniku:

Obaczyt krol że go barzo NALEGALI: onym gwattem przymuszony wydat im Daniela. Leop Dan 14/29 (SXVI);

Solicitator, Ten który NALEGA komu ocz/upominacz. Mącz 399c (SXVI);

[Torkwatus] nie chcial tego urzędu na się przyjąc//wymawiając się tym/że byt chory na oczy. A gdy go PRZYNAGLANO do tego: rzekt: Szukajcie kogo drugiego PP. Rzymianie PlutBud 4 (SXVI);

PRZYNAGLALI im [Żydom] Egipczycy aby co rychlej wyszli mówiąc/ iż pomrzemy wszyscy poki tu oni sq. BielKron 30 (SXVI).

W obu przypadkach forma $y$ w celowniku wycofała się z języka.

Problem komplikuje się, gdy uznamy niektóre wyrażenia przyimkowe za strukturalizacje drugiego argumentu przedmiotowego:

I wyszli Faryzeuszowiel i poczęli się z nim gadaćl DOMAGAJĄC SIĘ u niego znaku z nieba WujNT Mar 8/11 (SXVI); 
Duch św. DOMAGA SIĘ po nas/ mówiąc tak przez Dawida: Chwalcie Pana bębnem i piszczatka ModrzBaz (SXVI);

Bo pomni coś jest/ a jako ty masz czego DOCISKAĆ na nim/ boś jest jako nędzny robaczek a nikczemne ździebetko przed oczyma jego. RejPos 46v (SXVI).

Nie zawsze status tych wyrażeń jest jasny, potrzebne są dodatkowe narzędzia - sięgniemy do nich we fragmencie 4 . naszego tekstu.

3.2. Wachlarz struktur odnoszących się do $Z_{2}$ był niegdyś szerszy niż obecnie. Przede wszystkim zanika nominalizacja wprowadzana przyimkiem ku (przymuszać, nakłaniać, namówiać ku czemu), cytatów nie podajemy, bo wygasanie przyimka $k u$ znane jest każdemu polskiemu lingwiście. Ciekawsze są przykłady, w których z kilku możliwych strukturalizacji $Z_{2}$ pozostała jedna bądź dwie możliwości.

I tak dawniej przymuszać można było do czegoś i na coś - dziś tylko przymuszamy do czegoś.

Kto PRZYMUSZA drugiego do upicia w obyczaj przyjaźni albo zachowania/ niech będzie srodze strofowan WerGośc 268 (SXVI);

Ale jeśli by co przykazowali [moi przetożeni]/albo na co PRZYMUSZALI co by było przeciw panu bogu/i pismu świętemu/nie powinienem ich shuchać SeklWyzn f3v (SXVI).

Podobnie stało się z walencją czasowników nakłonić i podżegać. U progu polszczyzny można było nakłonić/ podżegać kogoś do czego, ale i nakłonićl podżegać na co, por.

Dat się Olgerd do stusznego jednania i przymierza NAKŁONIĆ StryjKron 421 (SXVI);

A iż żadnym sposobem nie chcemy się dać NAKEONIĆ na to co się nam jeти podoba? ModrzBaz 143v (SXVI).

Co za duch na mię zawzięty PODŻEGA cię do zdradzania mię? Teat. 6, 117 (SL); 
A gdzieby was chciat przedsię Szatan PODŻYGAĆ na pomstę/stuchajcież jako radzi Duch święty. Nie dajcie miejsca Szatanowi StryjKron 562 (SXVI).

Z dwu możliwości do czasów nam współczesnych pozostała tylko jednanakłonić/ podżegać do czego. Wiązanie wyrażenia na coś w funkcji $\mathrm{Z}_{2}$ miały też czasowniki podburzać, podszczuwać, poradzić, podwodzić, powabiać (na rękę, tzn. 'na pojedynek'), cisnać, poduszczać.

3.3. Ciekawie $w$ materiale historycznym wyglądają konstrukcje nakłaniania $\mathrm{z} \mathrm{Z}_{2} \mathrm{w}$ postaci bezokolicznika - nie tylko przy znanych nam kazać, ra$d z i c ́$, polecać, ale też innych:

NAMAWIAŁ go z soba do jakiegoś folwarku kraść. Lib Mal 1544/81 (SXVI)

Oto szatan [...] DOMAGAL SIE podsiać was jako pszenicę MurzNT Luc 22/31 (SXVI) ${ }^{11}$;

Bo ten żyd ma wiele przyjaciót i bratów, aby nie NAPRAWILI zabić kogo poszli pan nasz. LibLeg 11/61 (SXVI).

PROSZĄ tego przysiężnika wstać OrtOssol 32,3 (SStp).

I być może tu mamy wytłumaczenie szerokiego wachlarza funkcji prosić w 1 os. czasu teraźniejszego - od uprzejmej prośby (Proszę przyjać te kwiaty) po rozkaz (Proszę wyjść!) - w połączeniach innych niż proszę bezokolicznik jest niemożliwy. Zwroty te można traktować jako użycia prosić z archaicznym bezokolicznikiem - oczywiście nie jest to już proszenie, a nawet w ogóle nakłanianie choćby dlatego, że pozycja $y$ jest zablokowana - nie mówimy Proszę ciebie/ cię iść.

$\mathrm{Z}$ braku miejsca nie będziemy rozwijać problemu korzyści łączenia planu języka współczesnego z przeszłością. Jedno jest pewne - historykowi języka są potrzebne studia nad współczesnością, jest wtedy zorientowany w identyfikacji rozpatrywanych zagadnień (czasami identyfikacja zawodzi!), z drugiej strony - historia interpretuje niektóre właściwości współczesnego języka - wynika to z nieliniowej ewolucji każdego języka naturalnego.

11 Ten sam fragment w Tyś brzmi: 31 Szymonie, Szymonie, oto szatan domagat się, żeby was przesiać jak pszenicę; 32 ale Ja prosiłem za tobą, żeby nie ustała twoja wiara. Ty ze swej strony utwierdzaj twoich braci. 
4. Przyjęcie zaproponowanego abstrakcyjnego modelu pozwala zakreślić interesujący nas obszar języka nie tylko w polszczyźnie, daje się stosować do studiów konfrontatywnych, zwłaszcza slawistycznych. Mamy już pierwszy krok wiązania semantyki z właściwościami walencyjnymi wyrażeń predykatywnych. Mam tu na uwadze książkę Podstawowe struktury zdaniowe współczesnych języków słowiańskich: białoruski, bułgarski, polski, pod redakcją naukową Aleksandra Kiklewicza i Małgorzaty Korytkowskiej. Autorzy przełamują jedność rdzenia, nadrzędna jest semantyka z tym, że językiem „wiodącym”, swoistym tertium comparationis jest język polski. Jemu podporządkowane są odpowiedniki białoruskie i bułgarskie, dodać tu można słowackie, bo Maria Papierz (Papierz 2013) stosuje tę samą technikę opisu (obie pozycje dedykowane są Stanisławowi Karolakowi). Niestety, w materiale obu książek wykładników pojęcia nakłanianie jest niewiele, mieszczą się one w ogólnej klasie predykatów trójargumentowych kauzatywnych $\mathrm{z}$ omawianych $\mathrm{w}$ naszym tekście czasowników znalazły się tylko prosić, $k a$ zać, pozwalać/ pozwolić.

Ale nawet już tak skromny materiał pokazuje, że to, co obserwujemy w historii polszczyzny, odnaleźć można w innych językach. I np. problematyczne było uznanie realizacji drugiego argumentu przedmiotowego w postaci wyrażenia z przyimkiem na: Na sejmie w Radomiu DOPIERALI SIE [Panowie litewscy] tego na Michale Glińskim co im za winę miat dawaćl jako powiedat przed krolem BielKron 402v (SXVI). Tymczasem podobną postać może mieć $y \mathrm{w}$ języku bułgarskim w połączeniu $\mathrm{z}$ czasownikami: заповядвам 'rozkazywać', нареждам 'nakazywać', възлагам 'polecać/ zlecać', подшушвам 'szepnąć/podpuścić, подхвърлям 'zasugerować/podpuścić'; także ze złożonymi wyrażeniami predykatywnymi (frazeologizmami) nakłaniania typu пущзам (някаква) муха 'podpuszczać/nakłaniać kogoś do zrobienia czegoś (zwykle złego), por. Иван заповяда на Петър да излезе om cmasma (Jan kazał Piotrowi wyjść z pokoju). W języku bułgarskim, jak wiadomo, nie ma przypadków - funkcje przypadków zostały przejęte przez konstrukcje analityczne z przyimkami.

Powyższą cechę (uważaną za cechę bałkańską) bułgarszczyzna dzieli z innymi językami bałkańskimi. I np. w języku nowogreckim argument $y$

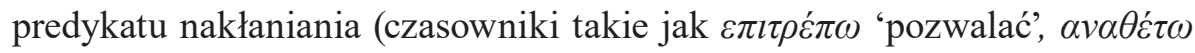

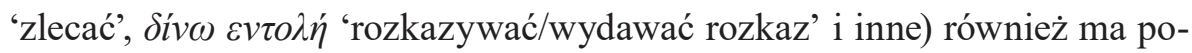
stać analitycznej konstrukcji z przyimkiem $\sigma \varepsilon$ 'na' $\left(\sigma \varepsilon^{\wedge} N P\right)$. W wyniku ana- 
logicznych procesów jak w bułgarskim (a raczej odwrotnie - w bułgarskim analogicznie do greckiego) $\sigma \varepsilon^{\wedge} N P$ przejęła funkcje celownika, por.:

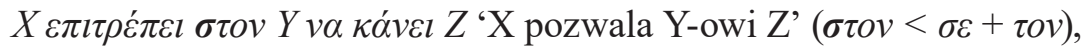

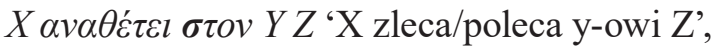

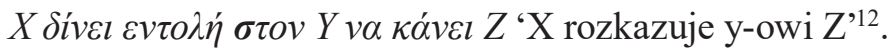

Model nakłanianie możemy odnaleźć również w tak odległym języku, jak hebrajszczyzna biblijna sprzed wielu wieków i należąca do innej rodziny językowej. Oczywiście będą tu już obowiązywać całkowicie odmienne wyznaczniki morfologiczno-składniowe i leksykalne. Niemniej model zachowuje swoją moc. Np. w zdaniu z Księgi Kapłańskiej:

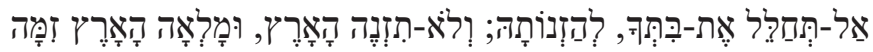

które można przetłumaczyć „Nie bezcześć swej córki, nakłaniając ją do zdrady, a i kraj nie pogrąży się w zdradzie i nie napełni się nierządem” (Kpł 19,29), dwukrotnie występuje rdzeń $\mathrm{ZN}(\mathrm{H})$, który w formie podstawowej znaczy m.in. 'zdradzać, uprawiać nierząd, być niewiernym', a w formie kauzatywnej powiększa rekcję o nowego, „skutkowego” aktanta - "namawiać do zdrady, czynić nierządnicą, skłaniać do niegodziwości, rozpusty, nikczemności’ W językach semickich uniwersalne pojęcie kauzatywności jest znacznie szersze niż w językach europejskich (Termińska 2009).

\section{Zakończenie}

W konwersatorium Stanisława Karolaka w latach siedemdziesiątych (pracował wtedy na Uniwersytecie Śląskim), choć realizowany był temat „Składnia konfrontatywna wyrażeń predykatywnych w języku polskim, francuskim i włoskim", uczestniczyli, prócz polonistów, reprezentanci slawistyki, anglistyki, germanistyki oraz semitystka Kamilla Termińska. Metodologia wypracowana na tzw. seminariach Karolakowskich była wynikiem dysku-

12 W tym miejscu pragniemy podziękować koleżance dr hab. Ilianie Genew-Puhalewej za pomoc w szukaniu analogii między językiem polskim a językami bałkańskimi. 
sji z ówczesnymi, nadal aktualnymi koncepcjami lingwistycznymi; spotkania zaowocowały wieloma pracami naukowymi. Niniejszy artykuł należy traktować jako powstały z ich inspiracji. Wypracowany wówczas zasadniczy rdzeń metodologiczny okazał się na tyle instruktywny, że ulegając różnorakim przekształceniom, redukcjom i rozszerzeniom nie został dotychczas zanegowany ani definitywnie porzucony. Nadal powstają prace uszczegóławiające koncepcję Karolaka (Czekańska 2015), powstają też propozycje jej rozszerzenia. Takie zadanie postawiły przed sobą autorki niniejszego tekstu.

\section{Wykaz źródeł}

SBor - BoRYś W., 2005, Słownik etymologiczny języka polskiego, Kraków: Wydawnictwo Literackie.

SDor - Donoszewski W. (red.), 1958-69, Stownik języka polskiego, t. 1-11, Warszawa: Wiedza Powszechna, Państwowe Wydawnictwo Naukowe.

SL - Linde S.B, 1854-1860, Stownik języka polskiego, wyd. 2, oprac. A. Bielowski. T. 1-6, Lwów (wydanie pierwsze Warszawa 1807-1814).

SXVI - Mayenowa M. R., PePlowski F. (red.), 1966-2012, Słownik polszczyzny XVI wieku, t. 1-36, Wrocław-Warszawa-Kraków: Ossolineum, Warszawa: IBL PAN.

Tyś - Pismo Święte Starego i Nowego Testamentu (tzw. Biblia Tysiąclecia), 2003, [online:] http://biblia. deon.pl/menu.php?st_id=1.

SSław - SŁaWski F., 1952-1982, Słownik etymologiczny języka polskiego, t. 1-5, Kraków: Towarzystwo Miłośników Języka Polskiego.

SWil-Zdanowicz A. i in., Stownikjęzyka polskiego,1861, t. 1-2, Wilno: Wydany staraniem i kosztem $M$. Orgelbranda..

SStp - UrbaŃCZYK S. (red.), 1953-2002, Stownik staropolski, t. 1-11. Wrocław-Warszawa-Kraków: Instytut Języka Polskiego PAN.

\section{Bibliografia}

CzeKańsKa M., 2015, Polskie czasowniki naklaniania jako nazwy tzw. czynności perlokucyjnych, Warszawa [maszynopis pracy doktorskiej].

Grymel J., KleszCZowa K., TermiŃsKa K., 1984, Les constructions décrivantes l'incitation, Neophilologica, t. 3, s. 42-55.

Hintikкa J., 1992, Eseje logiczno-filozoficzne, przeł. A. Grobler, Warszawa: Państwowe Wydawnictwo Naukowe. 
KArolak S., 1984, Składnia wyrażeń predykatywnych, w: Z. Topolińska (red.), Gramatyka współczesnego języka polskiego. Składnia, Warszawa: Państwowe Wydawnictwo Naukowe, s. 11-211.

Kiklewicz A., KorytKowskA M.(red.), 2010,Podstawowestrukturyzdaniowe wspótczesnych języków słowiańskich: białoruski, bułgarski, polski, Olsztyn: Centrum Badań Europy Wschodniej Uniwersytetu Warmińsko-Mazurskiego.

Kleszczowa K., 1993, Izolowanie leksyki erotycznej, w: R. Piętkowa (red.), Eros-psyche-seks. Materiały z konferencji Język a erotyka, Katowice: Wydawnictwo UŚ, s. 77-86.

Kleszczowa K., Termińska K., 1983, Nakłaniające zdania aluzyjne, Język Polski LXIII, s. 33-41.

Kleszczowa K., Termińska K., 1983, Wypowiedzenia rozkaźnikowe, Socjolingwistyka, nr 5, s. 115-127.

Kleszczowa K., Termińska K., 1985, Modus loquendi. Próba typologii, w: H. Wróbel (red.), Prace naukowe Uniwersytetu Ślaskiego w Katowicach. Prace Językoznawcze 10: Z problemów współczesnej polszczyzny, Katowice, s. 42-50.

Kleszczowa K., TermińsKa K., 1993, Aspekt czasownika a znaczenie zdania, Folia Philologica Macedono-Polonica, t. 2, s. 53-62.

Kleszczowa K., TermińsKa K., 1999, Werbalne i niewerbalne sposoby nakłaniania, w: W. Banyś, L. Bednarczuk, S. Karolak (red.), Studia lingwistyczne ofiarowane Profesorowi Kazimierzowi Polańskiemu na 70-lecie Jego urodzin, Katowice: Wydawnictwo Uniwersytetu Śląskiego, s. 54-62.

PAPIERz M., 2013, Podstawowe struktury składniowe współczesnego języka słowackiego, Kraków: Wydawnictwo Lexis.

Russell B., 2000, Nasza wiedza o świecie zewnętrznym jako pole badań dla metody naukowej w filozofii, przeł. T. Baszniak, Warszawa: Fundacja Aletheia.

TermiŃsKa K., 1983, Składnia czasowników kauzatywnych we współczesnym języku polskim. Katowice: Wydawnictwo Uniwersytetu Śląskiego.

TermińsKa K., 2001, Słowotwórstwo - z porządku w chaos i z powrotem. Czasowniki odczasownikowe, Polonica, t. 21, s. 287-302.

TermińsKa K., 2009, Kauzacja w klasycznym języku hebrajskim. Morfologia, semantyka i problemy terminologiczne, w: H. Fontański, R. Molencki, O. Wolińska, W kręgu teorii. Studia językoznawcze dedykowane Profesorowi Kazimierzowi Polańskiemu in memoriam, Katowice: Wydawnictwo UŚ, s. 234-246. 


\section{Transcending the boundaries of Stanisław Karolak's semantic syntax} ( s u m m a r y)

The authors - participants of the seminar devoted to the "Comparative syntax of predicative expressions in Polish, French and Italian", conducted by Stanisław Karolak in the 1970s - decided to suggest an extension of the PSPA concept of syntax (podstawowa struktura predykatowo-argumentowa - the basic predicativeargumentative structure). They selected the predicates of persuasion because they studied them during their work with Professor Karolak (consult the Bibliography). For this purpose, they developed the abstract predicative-argumentative structure for a greater class, thus nullifying the requirement of the identity of the root as well as the differences in the content of the particular predicates. Therefore we may say that it is a model of the concept of persuasion. The validity of linking the exponents of the abstract predicate which have dissimilar roots is accounted for by the semantic morphological-syntactic restrictions, therefore the model that is put forward may be referred to as the conceptual model which is supported by the paradigmatic syntax. The model covers powodowac 'to cause something', which is a clear indication that the predicates of persuasion belong to a more general class of causatives. In order to reject the plethora of various types of causation, the authors applied a morphologicalsyntactic filter.

In the further part of the text the authors put forward an internal division of the concept of persuasion on the basis of syntactic and morphological exponents. Therefore a separate class is constituted by the predicates of the benefit for $\mathrm{x}$ (prosic 'to ask for something', błagać 'to beg', the former modlić kogoś o coś); a different group is constituted by the predicative expressions such as the following radzić 'to advise somebody to do something', zalecać 'to recommend somebody to do something', podszeptywać 'to suggest something to somebody', in which the resultative event is beneficial to $y$; the class of predicates with the meaning ' $\mathrm{x}$ acts intentionally so that $\mathrm{y}$ does not do $\mathrm{Z}_{2}$ ' (odciagać 'to dissuade from', odwodzić 'to discourage from', ostrzegać 'to warn against', wyperswadowac' 'to reason somebody out of something', zabraniać 'to forbid', powstrzymywać 'to keep somebody from doing something'). The focus of the authors is on the class of predicates which takes into account evaluation, especially negative evaluation: podpuszczać 'to lead somebody on', judzić 'to incite', podżegać 'to instigate' etc.

The model that is presented in the article enables us to establish and interpret the area of language in question not only in the modern Polish language, but also in the historical Polish language. Moreover, the model may be applied to comparative studies. 
